\title{
In Vitro Koşullarda Farklı İki Nanohibrit Akışkan Kompozitin Derin Class II Kavitelerde Mikrosızıntı Açısından Değerlendirilmesi
}

\author{
Anıl ÇETİN*
}

\section{$\ddot{O} \mathbf{z}$}

Amaç: Mine-sement sınırının altında hazırlanan kavitelerde mikrosızıntı ile mücadele edebilmek oldukça güçtür. Bu nedenle çalışmanın amacı derin class II kavitelerdeki stres ve marginal bölgedeki kapanma problemlerinin çözümüne yönelik son yllarda sağlanan teknolojik ilerlemelerle geliştirilen nano dolduruculu kompozitlerin akışkan formlarının açık sandviç tekniği ile restore edilen derin kavitelerdeki etkinliğinin incelenmesidir.

Yöntem: 60 adet dişe standart meziyo-okluzal (MO), aproksimal kutu (box) şeklinde kaviteler, oklüzo-gingival derinliği mine-sement sınırının $1 \mathrm{~mm}$ altında olacak şekilde ve aproksimal kutunun ebatları 2x4×6 mm olacak şekilde açılmıştır. Restorasyonları bitirilen dişler rastgele seçilerek 3 gruba ayrılmıştır ( $\mathrm{n}=20$ ). Grup 1 kontrol grubudur ve kaviteler direkt kompozit (Filtek Z250) uygulaması ile bitirilmiştir. Grup 2 de basamakta Supreme XT Flow, Grup 3 te basamakta Grandio Flow kullanılmış olup, her 3 grubun üst yapıları mikrohibrit kompozit rezin (Filtek Z250) ile restore edilmiştir. Tüm örnekler termo-mekanik yüklemeye maruz bırakılarak yaşlandırılmıştır. Mikrosızıntı tayini bazik fuksin boyasının penetrasyon miktarının stereomikroskop (X40) altında incelenmesi ile yapılarak istatistiksel analize tabi tutulmuştur.

Bulgular: Sonuçların değerlendirilmesinde Mann Whitney U Test kullanılmıştır. Her iki nano dolduruculu akışkan kompozitler Supreme XT Flow ve Grandio Flow kontrol grubunda yer alan mikrohibrit rezine istatistiksel olarak anlamlı bir üstünlük sağlayamamışlardır ( $p>0,05)$. Ayrıca Supreme ve Grandio materyallerinin mikrosızıntı dereceleri arasında istatistiksel olarak anlamlı bir farklılık bulunamamıştır ( $\mathrm{p}>0,05)$.

Özgün Araştırma Makalesi (Original Research Article)

Geliş / Received: 12.11.2020 \& Kabul / Accepted: 26.11.2020

DOI: https://doi.org/10.38079/igusabder.825208

* Uzm. Dr., Bağımsız Araştırmacı, İstanbul, Türkiye, E-posta: dranilcetin@hotmail.com

ORCID https://orcid.org/0000-0002-0963-4769 
Sonuç: Nanohibrit akışkan kompozitler kendilerinden beklenen derin class II kavitelerdeki mikrosızıntıyı azaltma konusunda daha üstün özellikler sergileyememiştir.

Anahtar kelimeler: Mikrosızıntı, nanokompozit, termo-mekanik yükleme.

\title{
In-Vitro Microleakage Evaluation of Two Different Nanohybrid Flowable Composites in Deep Class II Cavities
}

\begin{abstract}
Aim: It's difficult to cope with the microleakage in the cavities prepared below the cementoenamel junction. Therefore the aim of this study is to evaluate the efficiency of the flowable forms of nanofiller composites in deep cavities restored with open sandwich technique proposed for the solution of the stress and marginal seal problems.
\end{abstract}

Method: Standart MO (mesio-occlusal) box shaped cavities were prepared in 60 teeth. The occlusal-gingival depth of the cavities was prepared $1 \mathrm{~mm}$ below the cementoenamel junction and the dimensions of the approximal box is arranged to be 2x4x6 mm in depth. After finishing the restorations, the teeth were randomly selected to form 3 groups $(n=20)$. Group 1 was the control and the cavities were restored with direct composite resin (Filtek Z250). The gingival increment was Supreme XT Flow for Group 2, Grandio Flow for Group 3. The remaining parts of the cavities were restored with the microhybrid composite resin (Filtek Z250) for all groups. All the specimens forming each group were aged by thermo-mechanical loading. The evaluation of microleakage is performed by the determination of the amount of the penetration of basic fuchsin dye under a stereomicroscope (X40) and the data was statistically analyzed. Mann Whitney U Test is used for the assessment of the results.

Results: Both of the two nanohybrid flowable composites Supreme XT Flow and Grandio Flow did not perform statistically significant superior advantages regarding the microhybrid resin in the control group. $(\mathrm{p}>0,05)$. Additionally, no statistically significant result was obtained between the microleakage values of Supreme and Grandio materials. ( $p>0,05)$.

Conclusion: Nanohybrid flowable composite resins could not perform superior properties to reduce microleakage in deep class II cavities compared to that of a microhybrid composite resin.

Keywords: Microleakage, nanocomposite, thermo-mechanical loading.

\section{Giriş}

60 yılı aşkın süredir çeşitli araştırmalara konu olan mikrosızıntı sıvıların, tükürüğün, bakterilerin ve bakteriyel ürünlerin, çözünebilen iyon ve moleküllerin restoratif 
malzemeler ile prepare edilmiş diş dokuları arasındaki klinik olarak gözlemlenemeyen mikro boşluklardan geçişi olarak tarif edilir ${ }^{1}$ Mikrosızıntı miktarları, restorasyonların ömründen, marginal bölgedeki renk değişimlerinden, sekonder çürüklerin gelişiminden, pulpa dokusundaki iltihabi bir takım olaylardan ve postoperatif hassasiyetlerden sorumlu olduğu ileri sürülmüştürri-3. Dental restorasyonların açılmış olan kaviteleri kapatmadaki başarısızlığı karşımıza mikrosızıntı olarak çıkmaktadır. Birçok restoratif dental malzeme marginal bölgedeki kapanmayı ve dolayısıyla bakteriyel mikrosızıntıyı önlemede başarısız olmaktadır 4 .

Son yıllarda sağlanan teknolojik ilerlemelerle partikül büyüklükleri o,oo1 mikrona kadar düşürülmüştür. Bu büyüklükteki partiküller de nano-dolduruculu kompozitlerin üretilmesini sağlamıştır5,6. Bu alanda ilk üretilen kompozitler daha çok yapısal özelliklerinden dolayı, üretici firma tarafından ön bölge restorasyonları için önerilirken, nano-hibrit yapıda yeni üretilen kompozitler, hem ön hem de arka grup restorasyonlarda kullanılabilme endikasyonuna sahip oldukları bildirilmiştir7.

Günümüzde geliştirilen nano teknolojinin amacı, ürünleri hafif, dayanıklı ve ucuz üretebilmektir. Geleneksel teknolojinin tersine, küçük birimlerden bütünü oluşturmaktır ${ }^{8}$. Nano partiküllü kompozit materyallerin organik yapısı da, diğer geleneksel ve hibrit kompozitler gibi benzer polimer yapılardan meydana gelmektedir9. İnorganik yapıyı meydana getiren partiküller ise iki ayrı kısımdan oluşmaktadır. Bunlar8:

1- Silika nanofiller (nanomerler) 20-75 $\mathrm{nm}$

2- Zirkonya/Silika nanokümeler (nanocluster) 5-20 $\mathrm{nm}$.

Nanomer yapısı 25-75 $\mathrm{nm}$ boyutlarındaki aglomere olmamış tek tek partikülleri ifade etmektedir ve nanomerler kompozit organik yapısında ayrı ayrı bulunurlar. Nano doldurucuların geleneksel mikro dolduruculara göre daha küçük olmaları, organik yapı ile temas eden yüzey alanının artmasına ve inorganik faz-organik faz bağlantısının daha kuvvetli olmasına neden olmaktadır5,10.

Kompozit organik yapısına katılan nanokümeler (nanoclusters) ise $50 \mathrm{~nm}$ den küçük nanomerlerin gevşek bağlar ile meydana getirdiği yapılardır. Silika ve zirkonyum partikülleri içerir. Zirkonya/silika partikülleri topluluk şeklinde zayıf bağlantılı kümeler oluştururlar. Kümelerin partikül boyutları 0.60-1.4 $\mu \mathrm{m}$ arasında değişir. Zayıf bağlantılı 
kümeler, termodinamik faktörler yardımıyla, tek bir ünite gibi hareket ederler ve kompozitin monomer miktarının minimum olmasına yol açarlar ${ }^{8}$.

Doldurucu oranının yüksek olması, organik yapının hacimce azalmasına neden olmakta ve sonuç olarak polimerizasyon büzülme oranı da azalmaktadır. Bu oranın \% 1.5'lar civarına çekildiği bilinmektedir9-14. Ancak nano dolduruculu kompozitler ile yapılmış olan bazı çalışmalarda nanokompozitlerin su emilimlerinin yüksek olduğu ayrıca aglomere olmuş yapıların yük altında farklı karakter sergiledikleri ve bu nedenle mikrohibrit rezinlere kıyasla farklı mekanik özellikler gösterdikleri de rapor edilmiştir ${ }^{15-}$ 24 .

\section{Gereç ve Yöntem}

$\mathrm{Bu}$ çalışmada son 6 ay içerisinde 25-45 yaş arası bireylerden çekilen, üzerlerinde herhangi bir çürük lezyonu ve restorasyonu bulunmayan, atrisyon, abrazyon veya herhangi bir defekt görülmeyen 60 adet molar diş kullanılmıştır. Dişler, üzerlerinde bulunan tüm birikintilerden arındırılarak, \%10'luk tamponlanmış formalin ( $\mathrm{pH}$ 7.0) solüsyonunda bekletilerek dezenfeksiyonları sağlanmış olup, çalışma süresine kadar distile su içerisinde saklanmıştır.

60 adet dişe standart MO (meziyo-okluzal), aproksimal kutu (box) şeklinde kaviteler açılmıştır. Kavitelerin oklüzo-gingival derinliği mine-sement sınırının $1 \mathrm{~mm}$ altında olacak şekilde tasarlanmıştır. Kavitelerin hazırlanması esnasında aproksimal kutunun ebatları kumpas yardım ile ölçülerek tüm dişlere açılan kavitelerin boyutları standardize edilmeye çalışılmıştır. Ancak her dişin oklüzo-gingival derinliği farklı olduğundan, kavitelerin bu yöndeki ebatları yaklaşık 5 ila $6 \mathrm{~mm}$ arasında hazırlanmıştır. Kavitelerin bukko-lingual yöndeki genişlikleri $4 \mathrm{~mm}$ ve aksiyo-pulpal yöndeki (meziyo-distal derinlik) genişlikleri ise $2 \mathrm{~mm}$ olacak şekilde hazırlanmıştır. Tüm kaviteler yüksek devirli düz ve silindir elmas frez (Accurata, Almanya) kullanılarak su soğutması altında hazırlanmıştır. Kavite kenarlarına bizotaj uygulanmamıştır. Her 5 kavite açlımından sonra frez değiştirilmiştir. Dişler rastgele seçilerek 3 ana gruba ayrılmıştır $(n=20)$.

\section{Kontrol Grubundaki Örneklerin Hazırlanması}

Kontrol grubunu oluşturan dişlerin restorasyonları yapılırken üretici firmanın önermiş olduğu tüm uygulama prosedürlerine sadık kalınmıştır. Bu doğrultuda kavite duvarları 15 sn boyunca \%35'lik fosforik asit içeren etching ajan Scotchbond (3M ESPE, Seefeld, 
Almanya) ile asitleme işlemi yapılmıştır. 15 sn hava-su spreyi ile kavitenin tüm duvarları yıkanmıştır. Hava-su spreyinin ucu kavite yüzeyinden yaklaşık $10 \mathrm{~cm}$ uzaklıkta olacak şekilde 2 sn süreyle hava sıkılarak kurutulmuştur. Dentin bağlayıcı ajan Adper Single Bond 2, (3M ESPE, Seefeld, Almanya) kendine özel fırçaları yardımı ile tüm kavite yüzeylerine uygulanmıştır. Bağlayıcı ajan, bir quartz tungsten halojen ışık kaynağı (Hilux Ultraplus, Benlioğlu Dental, Ankara) ile 20 sn süre ile polimerize edilmiştir. Deneyde kullanılan tüm ışıkla polimerize olan materyaller aynı ışın cihazı kullanılarak polimerizasyonları sağlanmıştır. Işıklı cihazın gücü radyometre ile kontrol edilerek 600 $\mathrm{mW} / \mathrm{cm}^{2}$ olacak şekilde ayarlanmıştır. Kompozit materyali olarak 3M ESPE firmasının mikrohibrit bir kompoziti olan Filtek Z250 (3M ESPE, Seefeld, Almanya) kullanılmış olup, body rengi olarak A2 seçilmiştir. Tofflemire metal matriks bandı (Jensen JP-1, Almanya) yerleştirilmesinden sonra kompozit materyali kavitelere $2 \mathrm{~mm}$ kalınlı̆̆ geçmeyecek tabakalar halinde yerleştirilmiştir (incremental technique). Öncelikle kavitenin 1/3 gingival basamağına, sonra kavitenin orta 1/3 kısmına ve son olarak da oklüzal 1/3 kısmına kompozit materyali tabakalı bir şekilde yerleştirilerek, her tabaka 40'ar sn quartz tungsten halojen ışık kaynağı olan Hilux Ultraplus (Benlioğlu Dental, Ankara) ışıklı dolgu cihazı ile polimerize edilmiştir. Gruplardaki tüm restorasyonların, tamamlanmasından hemen sonra elmas bitirme frezleri (Accurata, Almanya) ile yüzeyler düzeltilmiş ve cila işlemleri için ise Sof-Lex cila diskleri (3M ESPE, Seefeld, Almanya) kullanılarak polisaj işlemi tamamlanmıştır. Bitirme ve cila işlemleri su soğutması altında gerçekleştirilmiş olup, her 5 dişte bir elmas bitirme frezi ve abraziv disk değiştirilmiştir.

\section{Supreme XT Flow Grubundaki Örneklerin Hazırlanması}

Kaviteleri hazırlanmış diş örneklerinin kavite duvarlarına kontrol grubunda anlatılan aynı asit ve bağlayıcı ajanlar uygulanmıştır. Dişlere Tofflemire metal matriks bandı (Jensen JP-1, Almanya) yerleştirilmiştir. 3M ESPE firmasının üretimi olan A2 renk kodlu nanohibrit akışkan kompozit materyali Filtek Supreme XT Flow, kavitenin yalnızca 1/3 gingival basamağına ve kalınlığı 2 mm'yi geçmeyecek bir tabaka halinde yerleştirilmiştir. Polimerizasyonu, Hilux Ultraplus ışıklı dolgu cihazı ile 20 sn ışıklanarak yapılmıştır.

Kavitenin geri kalan orta 1/3 kısmı ve son olarak da oklüzal 1/3 kısmı kontrol grubunda anlatıldığı gibi bitirilmiştir. 


\section{Grandio Flow Grubundaki Örneklerin Hazırlanması}

Grandio Flow grubundaki örneklerin hazırlanması esnasında Voco firmasının bu ürününün kullanımı ile ilgili önermiş olduğu tüm uygulama prosedürlerine bağlı kalınmıştır. Kavite duvarları 30 sn boyunca \%34.5'lik fosforik asit içeren Vococid (Voco, Cuxhaven, Almanya) etching ajan ile asitlenmiştir. Dentin bağlayıcı ajan Solobond M (Voco, Cuxhaven, Almanya) kendine özel firçaları yardımı ile tüm kavite yüzeylerine uygulanmıştır. 30 sn beklendikten sonra, hava spreyi yardımı ile yaklaşık 2 sn hava sıkılarak bağlayıcı ajanın kaviteye dağılması ve fazla olan kısmın kaviteden uzaklaştırılması sağlanmıştır. Polimerizasyon işlemi, 20 sn süre ile yine Hilux Ultraplus (Benlioğlu Dental, Ankara) QTH ışıklı dolgu cihazı ile yapılmıştır. Grandio Flow'un rengi yine A2 olarak belirlenmiştir. Dişlere Tofflemire metal matriks bandı (Jensen JP-1, Almanya) yerleştirilmiştir. Grandio Flow, kavitenin yalnızca 1/3 gingival basamağına ve kalınlığ 2 mm’yi geçmeyecek bir tabaka halinde yerleştirilmiştir. Polimerizasyonu, Hilux Ultraplus ışıklı dolgu cihazı ile 20 sn ışıklanarak yapılmıştır. Kavitenin geri kalan orta 1/3 kısmı ve son olarak da oklüzal $1 / 3 \mathrm{kısmı} \mathrm{kontrol} \mathrm{grubunda} \mathrm{anlatıldığ} \mathrm{gibi}$ bitirilmiştir.

\section{Termo-Mekanik Yükleme}

Her biri 20 adet diş örneğinden oluşan ve 3 farklı materyal ile restore edilmiş olan numuneler Çiğneme Simülatörü Cihazı (Nova, Konya, Türkiye) ile oklüzal yüzeyden mekanik yükleme yapılmıştır. Çiğneme simülatörünün kontrol panelinden uygulanacak olan yükün tur sayısı ve yükün uygulanma süresi ayarlanarak test işlemi başlatılmıştır. Her bir örneğe 6 aylık in-vivo kullanıma eşdeğer 50.000 kez $50 \mathrm{~N}$ kuvvetinde yük 0,5 Hz frekans ile uygulanmıştır.

Mekanik yük uygulamasının ardından, örnekler yine yaklaşık 6 aylık in-vivo kullanıma eşdeğer 5000 termal siklus işlemine tabi tutuldu. Termal siklus işlemi için örnekler $5^{\circ} \mathrm{C}$ ve $55^{\circ} \mathrm{C}\left( \pm 2^{\circ} \mathrm{C}\right)$ deki su banyolarında 30'ar sn bekleyecek şekilde termal siklus cihazı ayarlanmıştır.

\section{Mikrosızıntı Tayini}

Restorasyon sınırlarının haricinde kalan tüm diş yüzeyleri iki kat tırnak cilası ile örtülerek uygulanacak boyadan izole edilmesi sağlanmıştır. Sonrasında dişler minesement sınırının yaklaşık $5 \mathrm{~mm}$ altında olacak şekilde soğuk akril Panacryl (Arma, 
İstanbul, Türkiye) bloklarına gömülmüştür. Tüm örnekler \% 0,5’lik bazik fuksin boyası içinde 24 saat bekletilmiştir. Sonra dişler akan suyun altında yıkanarak boyadan arındırılmıştır. Tüm dişler, mesio-distal yönde ve restorasyonların ortasından geçecek şekilde hassas kesim cihazı Isomet 1000 (Buehler Ltd, Lake Bluff, IL, ABD) ile kesilmiştir. Kesim işleminin hemen ardından tüm örnekler stereomikroskopta (Leica $\mathrm{MZ}_{75}$, Heerbrugg, İsviçre) 40 kez büyütme (x40) altında incelenerek Tablo 1 de belirtilen skorlar yardımı ile sızıntı dereceleri saptanmıştır.

Tablo 1: Boya sızıntı yönteminde kullanılan skorlar ve açıklamaları

\begin{tabular}{|l|l|}
\hline SKORLAR & AÇIKLAMALAR \\
\hline Skor o & Boya penetrasyonu yok \\
\hline Skor 1 & Gingival basamağın 1/3'üne kadar olan boya penetrasyonu \\
\hline Skor 2 & Gingival basamağın 1/2'sine kadar olan boya penetrasyonu \\
\hline Skor 3 & Gingival basamağın 2/3’̈̈ne kadar olan boya penetrasyonu \\
\hline Skor4 & $\begin{array}{l}\text { Gingival basamağın tümünü içeren ve aksiyal duvara ulaşan boya } \\
\text { penetrasyonu }\end{array}$ \\
\hline
\end{tabular}

\section{Sonuçların İstatistiksel Analizi}

Çalışmada elde edilen bulgular değerlendirilirken, istatistiksel analizler için Statistical Package for Social Sciences (SPSS) for Windows 15.0 programı kullanıldı. Çalışma verileri değerlendirilirken tanımlayıcı istatistiksel metotların (Frekans) yanı sıra niceliksel verilerin karşılaştırılmasında parametreler normal dağılım göstermediğinden gruplar arası karşılaştırmalarda Mann Whitney U test kullanıldı. Sonuçlar \%95’lik güven aralığında, anlamlılık p<0,05 düzeyinde değerlendirildi.

\section{Bulgular}

Termo-mekanik yükleme ile yapay olarak yaşlandırılan örneklerin \%16'sında hiç sızıntı görülmezken; \%14'ünde kavite tabanının 1/3'üne kadar olan sızıntı, \%32'sinde kavite tabanının 1/2'sine kadar olan sızıntı, \%20'sinde kavite tabanının 2/3'üne kadar olan sızıntı ve \%18’inde tüm kavite tabanında sızıntı görülmüştür (Şekil 1). 
Şekil 1: Termo-mekanik Yükleme Sonrasındaki Mikrosızıntı Dağılımı

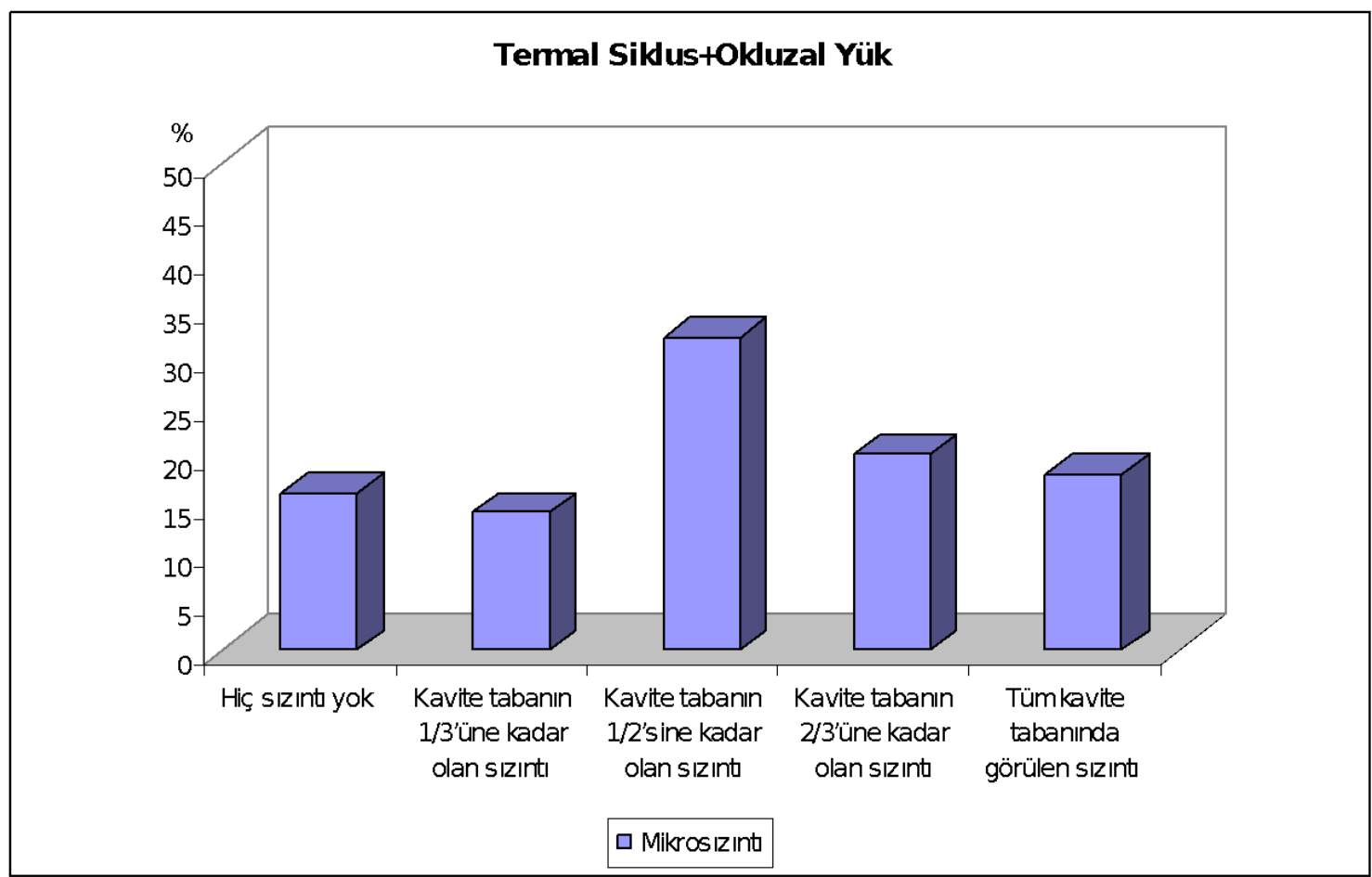

Kontrol grubundaki dişlerin \%20'sinde kavite tabanının 1/2'sine kadar olan sızıntı, \%50'sinde kavite tabanının 2/3'üne kadar olan sızıntı ve \%30’unda tüm kavite tabanında sızıntı görülmüştür. Supreme grubundaki dişlerin \%20'sinde kavite tabanının 1/3'üne kadar olan sızıntı, \%30’unda kavite tabanının 1/2'sine kadar olan sızıntı, \%20'sinde kavite tabanının 2/3'üne kadar olan sızıntı ve \%30’unda tüm kavite tabanında sızıntı görülmüştür.

Grandio grubundaki dişlerin \%10'unda kavite tabanının 1/3’üne kadar olan sızıntı, \%60'ında kavite tabanının 1/2'sine kadar olan sızıntı ve \%30'unda tüm kavite tabanında sızıntı görülmüştür (Şekil 2). 
Şekil 2. Termo-mekanik Yükleme Sonrası Materyallere Göre Mikrosızıntı Dağılımı

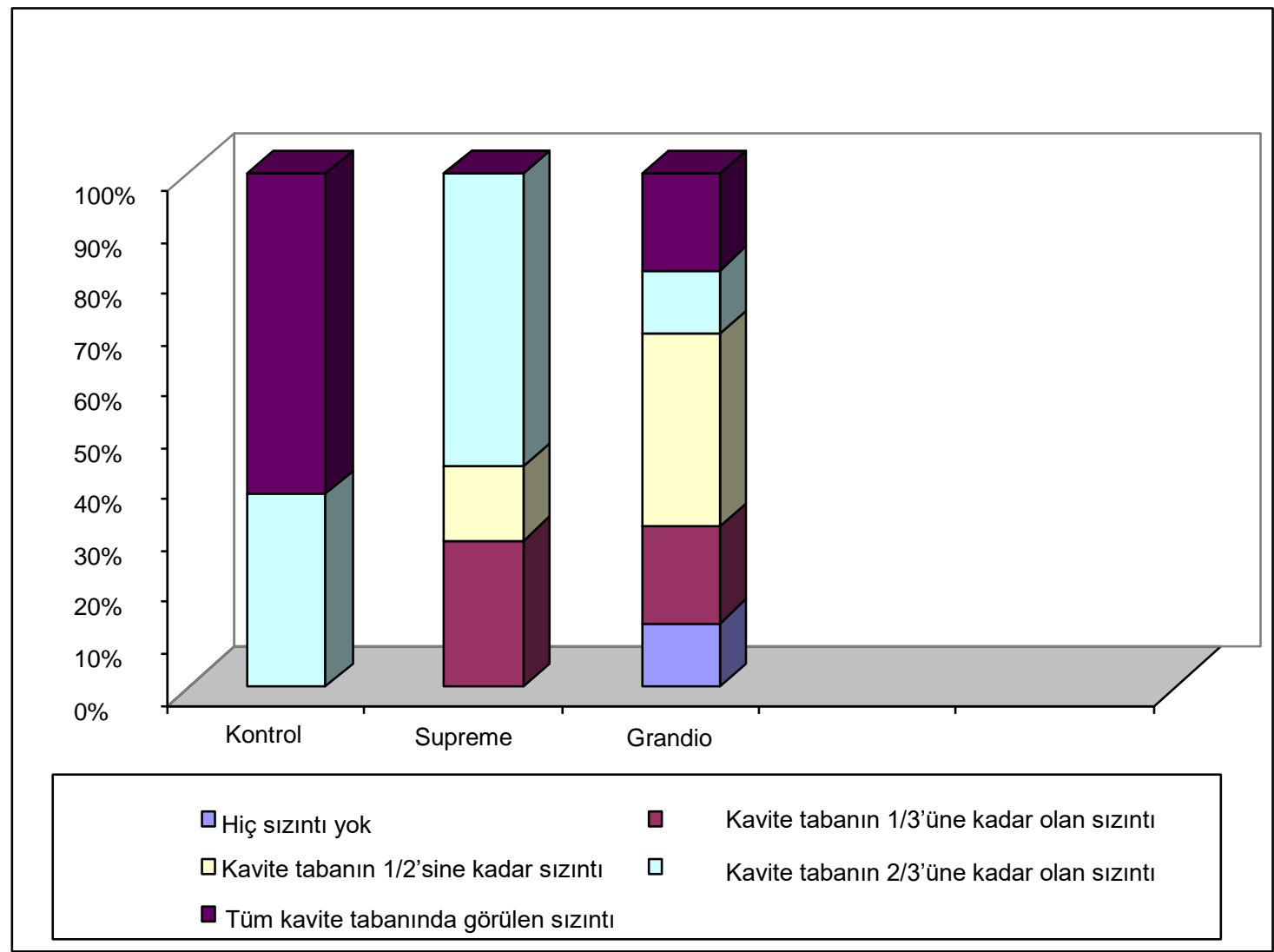

Kontrol ve Supreme materyallerinin mikrosızıntı dereceleri arasında istatistiksel olarak anlamlı bir farklılık bulunmamaktadır ( $\mathrm{p}>0.05$ ). Kontrol ve Grandio materyallerinin mikrosızıntı dereceleri arasında istatistiksel olarak anlamlı bir farklılık bulunmamaktadır (p>0.05). Supreme ve Grandio materyallerinin mikrosızıntı dereceleri arasında istatistiksel olarak anlamlı bir farklılık bulunmamaktadır (p>0.05) (Tablo 2). 
Tablo 2: Gruplara Göre Materyallerin Mikrosızıntı Derecelerinin Değerlendirilmesi

\begin{tabular}{|l|c|c|c|}
\hline \multirow{2}{*}{ Termo-Mekanik Yük } & \multicolumn{2}{|c|}{ Mikrosızıntı } & \multirow{2}{*}{$p$} \\
\cline { 2 - 3 } & Ort \pm SD & Medyan & \\
\hline Kontrol & $3,10 \pm 0,73$ & 3 & \multirow{2}{*}{0,323} \\
\cline { 2 - 3 } & $2,60 \pm 1,17$ & 2,5 & \\
\hline Kupreme & $3,10 \pm 0,73$ & 3 & \multirow{2}{*}{0,139} \\
\cline { 2 - 3 } & $2,50 \pm 1,08$ & 2 & \\
\hline Suprandio & $2,60 \pm 1,17$ & 2,5 & \multirow{2}{*}{0,840} \\
\cline { 2 - 3 } Grandio & $2,50 \pm 1,08$ & 2 & \\
\hline
\end{tabular}

Mann Whitney U Test kullanılmıştır.

\section{Tartışma}

Çalışmada kullanılan nanohibrit akışkan kompozitler olan supreme XT Flow ve Grandio Flow materyalleri termomekanik yükleme sonrasında mikrosızıntı açısından değerlendirildiğinde kontrol grubu ile arasında istatistiksel olarak anlamlı bir fark tespit edilmemiştir ( $\mathrm{p}>0,05)$.

Curtis ve $\operatorname{ark}^{15}$ yaptıkları çalışmada, nano doldurucu içeren kompozitlerin kısa ve orta dönem su emilimlerini ve mekanik özelliklerini geleneksel kompozit rezinler ile karşılaştırmışlardır. Doldurucu partiküllerin boyutları ve morfolojilerinin su emilimini ve dolayısı ile mekanik özelliklerini etkilediğini belirtmişlerdir. Nano dolduruculu kompozitlerde bulunan nano doldurucu partiküller ve nano kümeler (nano clusters) mikrohibrit rezinlere oranla hacimce daha geniş yüzey alanları içermektedir. Su emiliminden sorumlu tutulan hidrofilik silanın bu artmış olan yüzey alanlarına dağılmak zorunda oluşu yüksek oranda silanizasyon gerektirmekte ve bu nedenle kompozitlerin su emilimleri artmakta ve doldurucu-matriks arayüzünün yıkıma uğramasına sebep olmaktadır. Dolayısıyla nanofil kompozitlerde bulunan nano partiküllerin ve nano kümelerin (nano clusters) varlığının geleneksel mikrohibrit kompozitlere kıyasla fiziksel ve mekanik özelliklerinin farklılık göstermesine neden olduğunu savunmuşlardır. 
Çalışmada termomekanik yükleme sonunda nano dolduruculu akışkan kompozitler için elde edilen mikrosızıntı değerlerinin tatminkâr olmaması buna bağlanmaktadır.

Rüttermann ve $\operatorname{ark}^{16}$ yaptıkları çalışmanın sonunda elde ettiği verileri değerlendirdiğinde, termal siklus işleminden sonra Filtek Supreme XT’nin gerilme dayanıklılığının \%50 oranında düştüğünü, bu anlamlı düşüşün sorumlusunun materyal yapısında bulunan aglomere olmuş nano partiküllerin varlığı olduğunu bildirmiştir. Ayrıca bu yeni geliştirilmiş nano doldurucu içeren rezin bazlı restoratif materyallerin geleneksel mikrofil materyallere kıyasla üstün mekanik özellikler sergilemediğini ve su emilimi, suda çözünürlük ve gerilme dayanımı açısından mikrohibrit rezinlere kıyasla daha kötü mekanik performans sergilediklerini de rapor etmişlerdir. Çalışma Rüttermann ve $\operatorname{ark}^{16}$ 'nın verilerini desteklemektedir.

Janda ve $\operatorname{ark}^{17}$ mikrohibrit rezinler ile nano dolduruculu rezinlerin aynı matriks yapısına ve birbirine yakın doldurucu oranlarına sahip olmalarına rağmen, nano kompozitlerin yüksek su emilimi göstermelerinin nano doldurucuların varlığından ve aglomeratların (agglomerates) porlu yapısınından kaynaklandığını belirtmişlerdir. Çünkü bu porlu alanlara rezin matriksin tam anlamıyla infiltre olamaması sonucu, suda bekletme ve termal siklus işlemlerinden sonra su moleküllerinin bu alanları doldurduğunu rapor etmişlerdir.

West ve Malhotra ${ }^{18}$ nano doldurucular ile güçlendirilmiş polimerlerin içinde bulunan aglomeratların (agglomerates) nano kompozitlerin avantajlarını ortadan kaldırdığını, çünkü yük varlığında aglomeratların içerisinde kaymalar meydana geldiğini, bunun sonucunda partiküller ile polimer arasındaki bağlantı yüzey alanlarının azalması ile aglomeratların bulunduğu bölgelerden kırılmaların başladığını rapor etmişlerdir. $\mathrm{Bu}$ nedenle çalışmada uygulanan oklüzal yükün mikrosızıntı değerlerini arttırdığı kanısına varılmıştır. Ayrıca, yük uygulanımının termal siklus işleminin etkisini de attırmış olabileceğini düşünülmektedir.

Beun ve $\operatorname{ark}^{19}$ Grandio Flow'un mekanik özelliklerinin \% 80,2 oranında doldurucu içermesine rağmen, \%70 ila \%80 oranında ortalama doldurucu içeren üniversal kompozit rezinler ile aynı olduğunu rapor etmiştir. Çalışmanın sonunda Grandio Flow için elde edilen mikrosızıntı değerlerinin termo-mekanik yüklemeden sonra, kontrol grubunda kullanılan mikrohibrit kompozit rezinden farklı olmaması Beun ve ark ${ }^{19}$ çalışmalarını destekler niteliktedir. 


\section{Sonuç}

Çalışmada kullanılan nanohibrit akışkan kompozitler kendilerinden beklenen derin class II kavitelerdeki marginal mikrosızıntıyı azaltma açısından daha üstün özellikler sergileyememiştir.

\section{KAYNAKLAR}

1. Kidd EA. Microleakage in relation to amalgam and composite restorations. A laboratory study. Br. Dent. J. 1976;141:305-310.

2. Sano H, Takatsu T, Ciucchi B, Horner JA, Matthews WG, Pashley DH. Nanoleakage: leakage within the hibrid layer. Oper. Dent. 1995;20:18-25.

3. Bergenholtz G, Cox CF, Loesche WJ, Syed SA. Bacterial leakage around dental restorations: its effects on the dental pulp. J. Oral. Pathol. 1982;11:439-50.

4. Going RE, Massler M, Dute HL. Marginal penetration of dental restorations by different radioactive isotopes. J. Dent. Res. 1960;39:273-84.

5. Mitra SB, Wu D, Holmes BN. An application of nanotechnology in advanced dental materials. J Am Dent. Assoc. 2003;134:1382-1390.

6. Moszner N, Klapdohr S. Nanotechnology for dental composites. Int J. Nanotechnol. 2004;1:130-156.

7. Nalçacı A, Bağış B. Nano-hibrit bir kompozit rezinin yüzey sertliğinin in vitro olarak incelenmesi. A. ̈̈.Diş Hek. Fak. Derg. 2005;32:91-98.

8. Yücel T, Tarım B, Ulukapı H, Demirci M. Ön bölge dişlerde direkt estetik restorasyonlar. T.D.B.D. 2004;83:10-22.

9. Terry DA. Applications of nanotechnology. Pract. Proced. Aesthet. Dent. 2004;16:220-222.

10. Dabanoğlu A. Nano kompozitler. T.D.B. Dişhekimliğinde Klinik Dergisi. 2004;17:20-25.

11. Condon JR, Ferrance JL. Reduced polymerization stress through non-bonded nanofiller particles. Biomaterials. 2002;23:3807-3815. 
12. Duke ES. Has dentistry moved into the nanotechnology era? Compend. Cont. Educ. Dent. 2003;24:380-382.

13. Yap AU, Yap SH, Teo CK, Ng JJ. Comparision of surface finish of new aesthetic restorative materials. Oper. Dent. 2004;29:100-104.

14. Davis N. A nanotechnology composite. Compend. Contin. Educ. Dent. 2003;24:662-667.

15. Curtis AR, Shortall AC, Marquis PM, Palin WM. Water uptake and strength characteristics of a nanofilled resin composite. J. Dent. 2008;36:186-193.

16. Rüttermann S, Wandrey C, Raab WHM, Janda R. Novel nano-particles as fillers for an experimental resin-based restorative material. Acta Biomat. 2008;6:1846-1853.

17. Janda R, Roulet JF, Lata M, Rüttermann S. Water sorption and solubility of contemporary resin-based filling materials. J. Biomed. Mater. Res. 2007;82:545-551.

18. West RD, Malhotra VM. Rupture of nanoparticle agglomerates and formulation of $\mathrm{Al}_{2} \mathrm{O}_{3}$-epoxy nanocomposites using ultrasonic cavitation approach: effects on the structural and mechanical properties. Polym. Eng. Sci. 2006;46:421-430.

19. Beun S, Glorieux T, Devaux J, Vreven J, Leloup G. Characterization of nanofilled compared to universal and microfilled composites. Dent. Mater. 2007;23:51-59.

20. Illie N, Rencz A, Hickel R. Investigations towards nano-hybrid resin-based composites. Clin Oral Investig. 2013;17(1):185-93.

21. Sadechi M, Lynch CD. The effect of flowable materials on the microleakage of Class II composite restorations that extend apical to the cemento-enamel junction. Oper Dent. 2009;34(3):306-11.

22. Angerame D, De Biasi M. Do nanofilled/nanohybrid composites allow for better clinical performance of direct restorations than traditional microhybrid composites? A systematic review. Oper Dent. 2018;43(4):E191-E209. 
23. Alzraikat H, Burrow MF, Maghaireh GA, Taha NA. Nanofilled resin composite properties and clinical performance: A review. Oper Dent. 2018;43(4):E173E190.

24. Nagano D, Nakajima M, Takahashi M, et al. Effect of water aging of adherend composite on repair bond strength of nanofilled composites. J Adhes Dent. 2018;20(5):425-433. 